\title{
Utilization of Diethanolamide Surfactant from Methyl Esters of Palm Oil in Herbicide Formulation with Active Isopropylamine Glyphosate
}

\author{
DOI: $10.18196 /$ pt.2020.113.44-53
}

\author{
Ika Agustin Rusdiana*, Erliza Hambali, Mulyorini Rahayuningsih \\ Department of Agro-Industrial Technology, Faculty of Agricultural Technology \\ IPB University, Bogor 16002, Indonesia \\ *Corresponding author, email: ika.rusdiana@gmail.com
}

\begin{abstract}
A surfactant that can be developed from palm oil is non-ionic. Diethanolamine is a nonionic surfactant based on palm oil methyl ester, which can replace the use of polyoxyethylene amine surfactant in a commercial herbicide formula that harms the environment. This research aimed to determine the physicochemical properties of diethanolamine surfactant and to study the effect of diethanolamine surfactant addition in herbicide formulation with active ingredients of isopropylamine glyphosate. This study was arranged in a complete randomized design with surfactant concentrations as treatment, consisting of $7 \%, 2 \%, 3 \%, 4 \%, 5 \%, 6 \%, 7 \%, 4 \%, 5 \%, 6 \%, 7 \%, 8 \%$, and $9 \%(\mathrm{w} / \mathrm{W})$. The results showed that there was a significant effect of diethanolamine surfactant addition on the characteristics of the herbicide formulation. The concentration of $5 \%$ diethanolamine surfactant had the best character in producing herbicide with the lowest surface tension and a contact angle of 30.73 dyne/cm and $11.48^{\circ}$. The commercial herbicide, having a surface tension

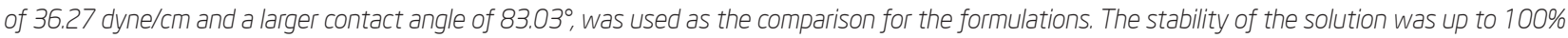
for 5 weeks at room temperature with solubility in water of $80.60 \%$ and a droplet size of $7.20 \mu \mathrm{m}$.

Keywords:Diethanolamine; Isopropylamine glyphosate; Non-ionic surfactant
\end{abstract}

\begin{abstract}
ABSTRAK
Surfaktan yang dikembangkan adalah surfaktan non-ionik dari minyak sawit. Dietanolamida merupakan surfaktan nonionik dari metil ester kelapa sawit yang dapat menggantikan penggunaan surfaktan polioksitilenamin dalam formula herbisida komersial yang berdampak negatif pada lingkungan. Penelitian ini bertujuan (1) untuk mengetahui sifat fisiko-kimia surfaktan dietanolamida yang dihasilkan, (2) untuk mengetahui pengaruh pemberian surfaktan dietanolamida dalam formulasi herbisida berbahan aktif isopropilamina g lifosat. Penelitian ini dirancang menggunakan rancangan acak lengkap satu faktor dengan perlakuan penambahan surfaktan dietanolamida 1\%, 2\%, 3\%, 4\%, 5\%, 6\%, 7\%, 8\% dan 9\% (b/b). Hasil penelitian menunjukkan adanya pengaruh nyata dari pemberian surfaktan dietanolamida terhadap karakteristik formula herbisida yang dihasilkan. Perlakuan konsentrasi surfaktan dietanolamida 5\% memiliki karakteristik terbaik dalam formula herbisida yang dihasilkan yakni nilai tegangan permukaan dan sudut kontak paling rendah sebesar 30,73 dyne/cm dan 11,480. Hasil formula tersebut berbeda nyata dengan herbisida komersial yang memiliki nilai tegangan permukaan sebesar 36,27 dyne/cm dan sudut kontak lebih besar yakni 83,030. Formula yang dihasilkan memiliki nilai stabilitas penyimpanan pada suhu ruang selama 5 minggu hingga 100\% dengan kelarutan formula herbisida dalam air sebesar 80,60\%. Ukuran droplet yang dihasilkan sebesar 7,20 $\mu \mathrm{m}$.
\end{abstract}

Kata Kunci: Dietanolamida; Isopropilamina glifosat; Surfaktan nonionik

\section{INTRODUCTION}

In the herbicide formulation, there is an active ingredient that is added in the form of an adjuvant to get the appropriate formula so that it can increase the effectiveness of the active ingredient used when applied. Herbicide formulations generally have high active ingredients around 25-65\%, and the rest are adjuvants (Tominack, 2010). In recent years, many herbicide products have been developed not only to maximize their efficiency and effectiveness in killing weeds but also to minimize al. (2014) suggested that one way to improve the performance of active ingredients and reduce the impact of environmental pollution is the addition of surfactants, which have a role in reducing negative impacts on biodiversity conservation.

The use of herbicides through spraying requires a type of surfactant that has wetting properties so that the herbicide solution gets wetter, thus increasing the effectiveness of the herbicide during application without interfering with the stability the impact of environmental pollution. Ghosh et of the active ingredients used in the herbicide 
formula. The role of surfactants can function as active compounds in wetting, dispersing, homogenizing, leveling, and attaching active ingredients to the surface of weed leaves. Surfactants that are often used in herbicide formulas are non-ionic surfactants, and some types of anionic surfactants and types that are not widely used in herbicide formulas are cationic surfactants (Tominack, 2000). The commercial herbicide formula commonly used by farmers usually consists of $48 \%$ glyphosate IPA, $15 \%$ polyoxyethylenamin surfactant (POEA), and water solvent. Chemical surfactants such as POEA in commercial herbicides exert a highly corrosive effect and have high toxicity to aquatic organisms and animals (Mesnage et al., 2015). Accordingly, it is necessary to find an alternative for safe and environmentally friendly surfactants. For this reason, the Surfactant and Bioenergy Research Center (SBRC) research team of IPB developed a type of non-ionic surfactant namely diethanolamine surfactant synthesized from the amidation reaction between diethanolamine and methyl ester of palm oil fatty acids where the surfactant diethanolamine has the lowest surface tension compared to alkyl polyglycoside, alkylphenol ethoxylates, and lauryl betaine (Suryani et al. 2012).

Recently, the demands for diethanolamine surfactants come from imports based on coconut oil and palm kernel oil, which are estimated to grow continuously due to their wide applications such as in the agrochemical industry, the cleaning industry, and the cosmetics industry. Besides, diethanolamine surfactants are more biodegradable and not toxic to the environment. The development of surfactants from palm oil aims to increase the added value of palm oil derivative products because Indonesia's palm oil production is very high so that the potential for development is very large. Based on the performance of diethanolamine surfactants in pesticides, Nisya et al. (2015) stated that diethanolamine surfactant from methyl ester of palm oil at a concentration of $6 \%$ was able to influence the effectiveness of insecticides made from buprofezin. The application of herbicide made from glyphosate IPA is carried out by spraying, which requires a type of surfactant to increase adhesion, especially when applied in the rainy season so that the surface of the weed leaves will get wetter. With the use of surfactants, the leaf surface covered with herbicide becomes wider, and the herbicide lasts longer on the surface of the weed leaf (Tominack, 2000). Herbicide formulation by Singarimbun (2012) using a 10\% lauric acid-based diethanolamine surfactant fractionated from $\mathrm{PKO}$ and $48 \%$ glyphosate IPA produced a formula with a viscous dark yellow visual appearance. The development of diethanolamine surfactants from methyl esters of palm oil is still not widely used in herbicides. For this reason, this study aimed to determine the physicochemical properties of the resulting diethanolamine surfactant and the effect of the addition of diethanolamine surfactant developed from methyl esters of palm oil in herbicide formulations with active ingredients of isopropylamine glyphosate.

\section{MATERIALS AND METHOD}

The study was conducted from December 2017 to January 2018 at the Surfactant and Bioenergy Research Center (SBRC) Laboratory of IPB Baranangsiang Bogor, West Java. The materials used in this research were diethanolamine, oil palm olein, $48 \%$ glyphosate isopropylamine, distilled water, methanol, $\mathrm{KOH}$, and $\mathrm{NaOH} 30 \%$. The stages of the research were as follows:

\section{Synthesis of diethanolamine surfactants}

Before the synthesis of the diethanolamine surfactant, the raw materials from palm olein were prepared through the transesterification process, 
resulting in a product in the form of methyl ester. The methyl ester was then heated to a temperature of $100^{\circ} \mathrm{C}$. After that, the diethanolamine surfactant was synthesized through an amidation process by reacting methyl ester and diethanolamine using a $30 \% \mathrm{NaOH}$ catalyst as much as $1 \%(\mathrm{w} / \mathrm{w})$ of all the total ingredients. The molar ratio of methyl esters and diethanolamine was $2: 1$. The amidation process required \pm 4 hours at $140^{\circ} \mathrm{C}$ with a stirring speed of $300 \mathrm{rpm}$ (Hambali et al., 2014). The results were then analyzed for their physicochemical properties, including density analysis (SOP for Densitymeter Anton Paar DMA 4500M), surface tension (SOP for Spinning drop tensiometer), viscosity (SOP for Brookfield DV-III ultra) and $\mathrm{pH}$ (SOP for Schott $\mathrm{pH}$ meter).

\section{Herbicide formulation}

Herbicide formulation made is a type of soluble liquid formulation with $48 \%(\mathrm{w} / \mathrm{w})$ glyphosate isopropylamine active ingredients according to commercial herbicide formula and the addition of diethanolamine surfactant in the formula of $1-9 \%(w / w)$ (Indrawijaya, 2016). The solvent then was added in the form of water. The weight of the formula for each treatment was 50 grams. The formulation was carried out using a homogenizer at a mixing speed of 2000-3000 rpm for 10-15 minutes (Hambali et al., 2015). The experimental design used in this stage was a completely randomized design with diethanolamine surfactant concentration as treatment, consisting of $1 \%, 2 \%, 3 \%, 4 \%$, $5 \%, 6 \%, 7 \%, 8 \%$ and $9 \%$. The formulation was replicated 2 times. Analysis of the formulas carried out were surface tension (SOP for Spinning drop tensiometer), contact angle (SOP for phoenix 300 Contact angle analyzer), droplet size (SOP for $\mathrm{Mi}$ croscope Leica ICC $50 \mathrm{HD}$ ), stability test of the formula for 5 weeks storage (Suryani et al, 2008), and solubility test in the formulation using Gravimetric method (Fardiaz et al., 1992). The successful formula is the formula with solution stability $>80 \%$, otherwise, it is considered unstable because it does not form a perfect solution (Elvina, 2015). Then the results of these observations were compared with commercial herbicides. The formula having the lowest surface tension and contact angle were selected in this study.

All data were analyzed using analysis of variance (ANOVA) at a 95\% confidence level and subjected to Duncan's further test at a 5\% error level using Statistical Product and Service Solution (SPSS).

\section{RESULTS AND DISCUSSION}

Physicochemical Properties of Diethanolamine Surfactants

Diethanolamine surfactant is a type of nonionic surfactant that is synthesized by an amidation reaction. The raw material used can be in the form of fatty acids or methyl esters that are reacted with diethanolamine using a basic catalyst. The surfactant used in this research was the result of palm oil olein synthesis in the form of methyl ester, which was reacted with diethanolamine producing by-products in the form of methanol. Before the herbicide was formulated, an analysis of the physicochemical properties of the diethanolamine surfactant was performed. The analysis aimed to determine the characteristics of the surfactant produced by diethanolamine, therefore determining the effects of the added surfactant on the characteristics of the herbicide formula produced. The characteristics of diethanolamine surfactants tested in this study are presented in Table 1.

Table 1. Physicochemical properties of diethanolamine surfactants

\begin{tabular}{ll}
\hline Physicochemical properties & Values \\
\hline Density & $0.9762 \mathrm{~g} / \mathrm{cm}^{3}$ \\
Surface tension & $32.21 \mathrm{dyne} / \mathrm{cm}$ \\
Viscosity & $257.35 \mathrm{cP}$ \\
$\mathrm{pH}$ & 11.10 \\
\hline
\end{tabular}


The diethanolamine surfactant produced showed a yellowish-brown color, and during storage, it experienced compaction. The purity of the DEA surfactant produced cannot be said to be $100 \%$, considering that during storage, there was still very little yellow liquid thought to be the residual methyl ester that had not reacted completely during an amidation reaction. According to Table 1 , the diethanolamine surfactant can reduce the surface tension of the water to $32.21 \mathrm{dyne} / \mathrm{cm}$. The surface tension of the diethanolamine surfactant on a laboratory scale ranges from 32.06 to 33.82 dyne/cm (Hambali et al., 2015). Diethanolamine surfactant can reduce surface tension because the surfactant is more likely to dissolve in water, which causes the movement of surfactant molecules to the surface of the water, thereby reducing its surface tension.

The viscosity characteristics are related to density. Density is the weight of a liquid per volume, and viscosity is the resistance to flow in a liquid. Density testing aims to determine the density between molecules in the diethanolamine surfactant produced. If the density has a higher value, then the liquid has a denser viscosity. The diethanolamine surfactants in this study had a density value that was almost the same as commercial coconut oilbased diethanolamine surfactant or called coco diethanolamine, which was equal to $0.995 \mathrm{~g} / \mathrm{cm}^{3}$, and the value was not much different from the results of Meizar's research (2016) of 0.9772-0.9798 $\mathrm{g} / \mathrm{cm}^{3}$. The viscosity of diethanolamine surfactants at room temperature ranges from 232.73-267.86 cP (Meizar, 2016). This value is not much different from the viscosity of the diethanolamine surfactants in this study, which was $257.35 \mathrm{cP}$. The $\mathrm{pH}$ value of the diethanolamine surfactants produced was 11.10 . These surfactants tended to be alkaline due to the raw materials and catalysts used in the synthesis of diethanolamine surfactants. Diethanolamine had a $\mathrm{pH}$ value of 11 , and the use of a base catalyst, in the form of $\mathrm{NaOH} 30 \%$, was as much as $1 \%$ of the total material used.

\section{Product of Herbicide Formulation \\ Surface tension}

Surface tension is the pressure from inside that occurs on the surface of a liquid due to the pulling force of molecules down the surface. Liquid surface tension is influenced by several factors, including liquid type, temperature, pressure, and density. Large liquid molecules such as water have a high surface tension due to an increase in intermolecular attractions (Indah, 2018). Measurement of surface tension was following the concentration of treatment, which was $1-9 \%$. According to Figure 1 , the surface tension of the herbicide was between $30.73-37.68$ dyne/cm. There was a significant effect of the diethanolamine surfactant concentration added in the herbicide formula on the surface tension properties. Based on Duncan's further test analysis, the addition of a $5 \%$ surfactant in the formula significantly resulted in the smallest surface tension value. It was assumed that the

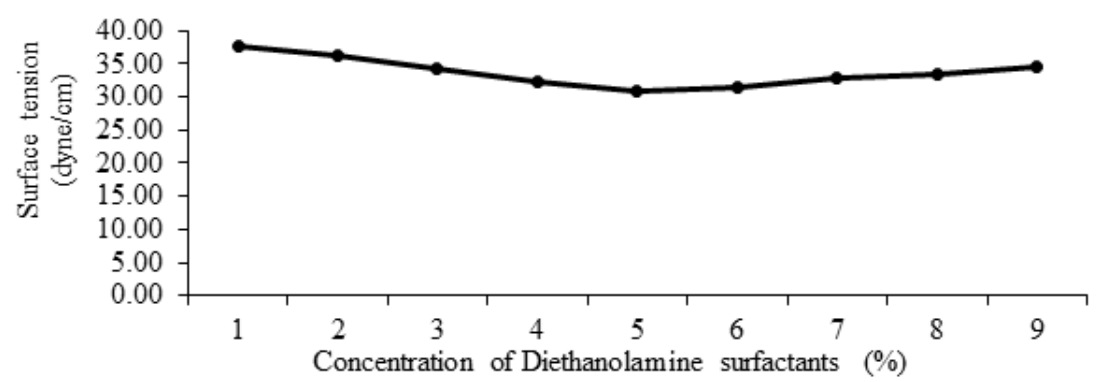

Figure 1. Effects of the concentration of diethanolamine surfactants in the herbicide formula on the surface tension 
diethanolamine surfactant was at the optimum condition with the lowest surface tension value at $5-6 \%$ because the surfactant concentration had reached the optimum Critical Micelle Concentration (CMC) value (Indrawijaya, 2016). CMC values indicate the critical concentration of surfactants in forming micelles, and the surfactants added in the system will spontaneously turn into micelles. During the formation of micelles in a surfactant solution, the surface tension of the liquid changes rapidly when the concentration of the solution increases, and when it reaches CMC, the surface tension is relatively constant or decreases with the lower slope (Mishra, 2015).

The addition of diethanolamine surfactant at a concentration of $1 \%-5 \%$ showed a decrease in the surface tension value from 37.68 to 30.73 dyne $/ \mathrm{cm}$. Meanwhile, the addition of diethanolamine surfactant at a concentration of more than $5 \%$ showed an increase in surface tension, and the highest increase was observed in the concentration of $9 \%$, which was 34.47 dyne $/ \mathrm{cm}$. The commercial herbicides showed a surface tension value of $36.27 \mathrm{dyne} / \mathrm{cm}$, which was almost the same with the value in the formulation treatment using a 2\% diethanolamine surfactant producing surface tension value of 36.29 dyne $/ \mathrm{cm}$. From this comparison, it can be concluded that the addition of a $5 \%$ diethanolamine surfactant resulted in the lowest surface tension value compared to commercial herbicides. At the optimum condition, the surface tension value will remain stable even though the surfactant concentration is increased because the concentration has reached a saturation limit, forming a collection of molecules (micelles) in dynamic equilibrium. The surface tension value of herbicide is related to the function of surfactant as an active compound in reducing surface tension. The presence of solvents in the form of water in the formula also influences the value of the surface tension due to the surfactant diethanolamine that is more soluble to water. The presence of a surfactant hydrophilic group bound to molecules on the surface of the liquid leading to this polar solvent causes a reduction in free energy in the solution of the herbicide formula. The reduction in energy occurs due to the division of bond energy between liquid molecules. While the hydrophilic group becomes long, the hydrophobic group of diethanolamine surfactant is shorter, causing the ability of the diethanolamine surfactant in the formation of micelles to decrease. The existence of balanced conditions between molecules on the surface of the liquid and a decrease in the bonding energy between molecules in the liquid by the surfactant causes a decrease in the surface tension value of the herbicide solution. A small surface tension value will increase the ability of a herbicide solution to penetrate into the interior of weed plant tissue. The diethanolamine surfactants that are more likely to dissolve in water then coat the walls of the globules. The role of the diethanolamine surfactant as an active compound to reduce surface tension can be maximum with the smaller and more uniform size of the globule as well as the wider surface of the wall that can be coated by surfactants (Ferdian et al., 2016). The surface tension characteristics of herbicide solutions are closely related to their ability to form contact angles. The smaller the surface tension value, the smaller the attraction between molecules in the solution so that the herbicide solution can spread on the surface of the weed leaves.

\section{Contact angle}

The test on the contact angle of the formula aims to show the ability of herbicide solution to quickly spread over the surface of a weed leaf. It was performed to determine the ability of surfactants to stick to and spread the active ingredient of glyphosate isopropylamine on the surface of weed 
leaves. This contact angle is formed between the surface of the weed leaf with a dripping herbicide and measured after 10 minutes to see its performance. The average contact angle resulted from the addition of the diethanolamine surfactant in the herbicide formula was between $11.48 \mathrm{o}$ to $42.87 \mathrm{o}$. There was a significant effect of diethanolamine surfactant concentration on the contact angles formed. The smallest contact angle was found in the surfactant treatment of $5 \%$, which was 11.48 o. Meanwhile, the largest value was observed in the commercial herbicide treatment, which was 83.03 o (Figure 2). Commercial herbicides formed a greater contact angle that was almost double that of the formulation treatment using a 1\% diethanolamine surfactant, which was equal to $42.87 \mathrm{o}$. The contact angle of commercial herbicides was greater than that of all formulation treatments, presumably due to the use of different surfactants. In commercial herbicides, $15 \%$ of POEA surfactants were used. This shows the effectiveness of the diethanolamine surfactant in reducing the contact angle of the formula produced. Conversely, the presence of more POEA surfactants in commercial herbicide formulas shows the ineffectiveness of the POEA surfactant performance on the contact angles formed, as evidenced by the contact angle value of commercial herbicides, nearly reaching $90^{\circ} \mathrm{C}$.

According to Figure 2, the addition of DEA surfactants at a concentration of $1 \%$ to $5 \%$ significantly decreased the contact angle. However, the addition of DEA surfactants at a concentration of more than 5\% significantly increased the contact angle. This difference is related to the smallest contact angle value in the addition of a $5 \%$ diethanolamine surfactant, indicating that herbicide solution can stick longer and spread faster evenly compared to commercial herbicides that produce a greater contact angle of $83.03 \mathrm{o}$. A small contact angle value is associated with a small surface tension value. The addition of a $5 \%$ diethanolamine surfactant resulted in the smallest surface tension value of 30.73 dyne/cm, while the commercial herbicide showed a higher surface tension value of 36.27 dyne/cm. Large concentrations of surfactants will reflect the dispersal behavior of leaves affected by the adsorption process and changes in the interface voltage balance energy (Ivanova and Starov, 2011). The small contact angle shows the surfactant performance as a wetting agent as well as the excellent spread of insecticide liquid on the leaf surface (Zhou, 2007). Contact angle approaching Oo indicates that the drops of herbicide solution can stick and spread very well on the surface of the weed, while the angle approaching 90o indicates that the solution drops on weed leaves can only stick, but the distribution is uneven (Hambali et al., 2015).

Storage stability of the herbicide formula for five weeks

The stability of the herbicide formula solution is one of the important characteristics because it has a significant influence on the quality of the formula produced (Suryani et al., 2000). The herbi-

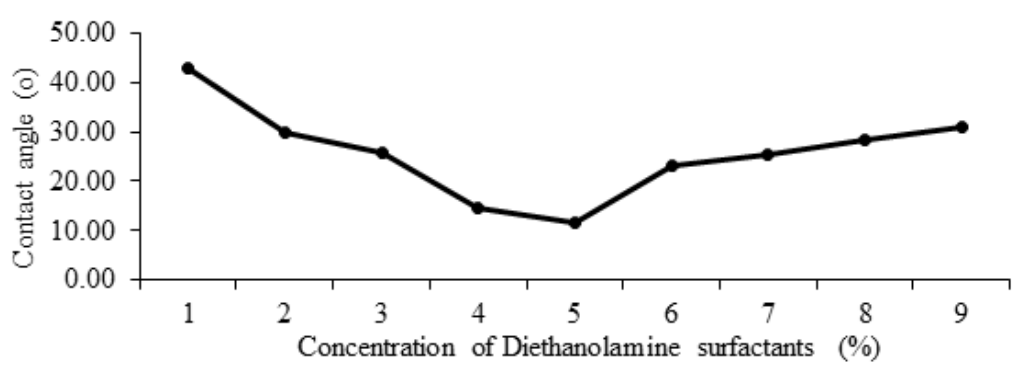

Figure 2. Effects of the concentration of diethanolamine surfactants in the herbicide formula on the contact angle 
cide formulation carried out in this study was $48 \%$ active glyphosate isopropylamine, diethanolamine surfactant with a concentration of 1 to $9 \%$, and solvent in the form of water. The use of glyphosate isopropylamine active ingredient is following the active ingredient used in commercial herbicide products. Solvents in the form of water were used in this formulation due to the nature of the active ingredient of glyphosate isopropylamine and the nature of the diethanolamine surfactant, which was more soluble to water. Formulas that have been successfully formed are those that have stability of solution $>80 \%$. After formulation, there was no change in the homogeneity. However, after storing for 5 weeks at room temperature, there was a change. Based on the results of ANOVA and Duncan's Multiple Range Test at 5\%, there was a significant effect of the concentration of diethanolamine surfactants on the stability of the formula.

The lowest average value of storage stability for 5 weeks at room temperature was observed in the addition of a $1 \%$ diethanolamine surfactant, which was $20 \%$. This treatment experienced a separation phase, starting from three days after formulation for 5 weeks. This result is not much different from the addition of diethanolamine surfactants at concentrations of $2 \%$ and $3 \%$. Meanwhile, the addition of surfactant at a concentration of $3 \%$ showed a stability value of $40.86 \%$, showing perfect stability when compared with the storage stability of commercial herbicides. The addition of a $4 \%$ diethanolamine surfactant resulted in stability value that was close to that of commercial herbicide, which was only about $25 \%$ difference. This result can be related to the characteristics of diethanolamine surfactants that are dense at room temperature, which can interfere with the stability of the formula. It was seen when the addition of surfactants at concentrations of $1 \%$ to $4 \%$ showed stability during storage of $<80 \%$ (Table 2 ). This happens because of the separation phase formed where the water phase and glyphosate isopropylamine active ingredient are at the bottom, and the surfactant phase of diethanolamine is at the top due to the specific gravity of the diethanolamine that is smaller than that of water. On the other hand, the addition of surfactant at concentrations of $5 \%$ to $9 \%$ showed the stability of up to $100 \%$, as shown by commercial herbicides. This is thought to be due to a balance between the forces that occur, namely the attractive force and repulsion between particles in the formula of herbicide solution. If this equilibrium force is maintained, then the particles in the solution do not unite so that the formula does not become two separate phases. The stability of the solution can reach the maximum if the repulsion force between the globules of the dispersed phase reaches a maximum (Aisha, 2011). If the surface of the newly developed liquid is unstable by surfactant molecules, then hydrophobic interactions can cause the aggregation and instability of the solution (Weiss et al., 2008). During the storage, there were no chemical changes related to the color and odor of the formula produced.

Table 2. Effects of diethanolamine surfactants on the storage stability, droplet size and solubility in water

\begin{tabular}{lcc}
\hline \multirow{2}{*}{$\begin{array}{l}\text { Surfactants } \\
\text { concentration }\end{array}$} & \multicolumn{2}{c}{ Average values of herbicide properties } \\
\cline { 2 - 3 } & Storage stability $(\%)$ & Droplet size $(\mu \mathrm{m})$ \\
\hline Diethanolamine 1\% & $20.00 \pm 0.00 \mathrm{a}$ & $9.37 \pm 0.07 \mathrm{~g}$ \\
Diethanolamine 2\% & $30.00 \pm 1.43 \mathrm{~b}$ & $8.31 \pm 0.02 \mathrm{f}$ \\
Diethanolamine 3\% & $42.86 \pm 0.00 \mathrm{c}$ & $8.23 \pm 0.03 \mathrm{ef}$ \\
Diethanolamine 4\% & $87.14 \pm 1.43 \mathrm{~d}$ & $7.69 \pm 0.34 \mathrm{de}$ \\
Diethanolamine 5\% & $100 \pm 0.00 \mathrm{e}$ & $7.20 \pm 0.02 \mathrm{~cd}$ \\
Diethanolamine 6\% & $100 \pm 0.00 \mathrm{e}$ & $6.93 \pm 0.05 \mathrm{bc}$ \\
Diethanolamine 7\% & $100 \pm 0.00 \mathrm{e}$ & $6.46 \pm 0.41 \mathrm{~b}$ \\
Diethanolamine 8\% & $100 \pm 0.00 \mathrm{e}$ & $5.58 \pm 0.02 \mathrm{a}$ \\
Diethanolamine 9\% & $100 \pm 0.00 \mathrm{e}$ & $5.29 \pm 0.01 \mathrm{a}$ \\
Commercial herbicide & $100 \pm 0.00 \mathrm{e}$ & $5.81 \pm 0.08 \mathrm{a}$ \\
\hline
\end{tabular}

Remarks: Means followed by the same letters in the same column are not significantly different according to Duncan Multiple Range Test at $5 \%$ 
Droplet size of the herbicide formula

Table 2. explains that the droplet size of the herbicide solution ranges between 5.29 to 9.37 $\mu \mathrm{m}$. There was a significant effect of the diethanolamine surfactants addition on the droplet size. The addition of a $9 \%$ surfactant produced the smallest droplet size of $5.29 \mu \mathrm{m}$. The higher the concentration of diethanolamine surfactant used, the smaller the size of the droplet. This is presumably due to the higher intermolecular collision forces as long as the surfactant can still work by covering the droplet surface. Duncan's further test results at 5\% explained that the addition of DEA surfactant at concentrations of $8 \%$ and $9 \%$ showed no significant effect compared to the commercial herbicides. High surfactant concentrations can stabilize the surface of newly developed fluids during the homogenization process, resulting in a smaller particle (Mcclements, 2012).

Meanwhile, the droplet size in commercial herbicide was fairly small, which was $5.81 \mu \mathrm{m}$. This value is nearly the same with the values resulted in the addition of diethanolamine surfactants at concentrations of $8 \%$ to $9 \%$, ranging from 5.58 $\mu \mathrm{m}$ to $5.29 \mu \mathrm{m}$. This difference occurs because the composition of the materials used is different, especially the surfactants. The droplet size affects the performance in the process of penetration and contact with weed surfaces. The smaller the droplet size, the greater the contact surface area with the surface of the weed so that the active ingredients contained in the formula can easily penetrate the weed tissue. Weiss and Muschiolik (2007) stated that an important factor determining the efficiency performance of bioactive materials is particle size because it determines the surface area in its distribution.

\section{Solubility of herbicide in the water}

One of the important properties of surfactants is the ability to increase the solubility of ingredients in herbicides, which is related to the application of herbicide in the field. Prior to the application, the herbicide is dissolved in water. Hence, the higher the solubility of the herbicide, the easier the application.

The solubility of the herbicide in this study ranged from $62.55 \%$ to $84.55 \%$. Based on the ANOVA results, there was a significant effect of the addition of diethanolamine surfactant on the herbicide's solubility in water. The results of Duncan's multiple range test showed that the higher the concentration of diethanolamine surfactant, the higher the water solubility (Figure 3). The highest percentage of solubility was observed in the addition of diethanolamine surfactant at a concentration of $9 \%$, which was $84.55 \%$. Meanwhile, the commercial herbicides showed a good solubility of $92.35 \%$. On the other hand, the herbicide formulations with the addition of a $1 \%$ diethanolamine surfactant showed the lowest solubility of $62.55 \%$. This poor solubility was presumably due to the presence of less homogeneous materials or surfactants in the formulation. The higher the DEA surfactant

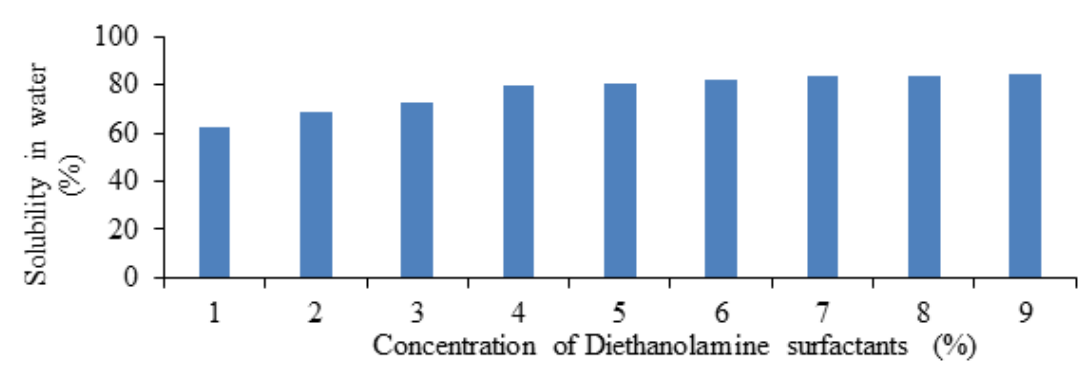

Figure 3. Effects of the concentration of diethanolamine surfactants in the herbicide formula on the solubility in the water 
concentration, the higher the solubility. This is likely due to the characteristic of the DEA surfactant that is more polar. These results illustrate that the formulation made in this study nearly reaches the solubility of commercial herbicides. This can be seen from the visual appearance of a commercial herbicide, which is in the form of liquid with golden yellow color and clear.

Good solubility is influenced by the droplet size that is smaller and more homogeneous so that the surface area is increased. Increasing the surface area can increase contact between the herbicide formula with water resulting in higher solubility. The solubility of a compound depends on the size and number of micelles present in the solution (Pilemand, 2002). Generally, there are two types of strengths affecting surfactant molecules in the water, namely, the repulsive force between the hydrophobic parts of a surfactant molecule and the attractive force between water particles of surfactant molecules (Aisyah, 2011). Besides, the solubility in water can also be related to the value of the hydrophilic-lipophilic balance system (HLB) surfactant. A low HLB value indicates the presence of a water-insoluble surfactant, while a high HLB value indicates the presence of a water-soluble surfactant. Diethanolamine surfactant functions as a wetting agent because its HLB value is in the range of 7-9, which is 7.24 , and it plays role in reducing the surface tension of the liquid and allowing it to accelerate penetration into the material (Suryani et al, 2000). The higher the concentration of diethanolamine surfactant given, the higher the solubility of the herbicide. This is because diethanolamine surfactants are more likely to dissolve in the water due to their more dominant polar groups so that surfactant molecules will be absorbed more strongly by water than oil, which causes lower surface tension and increased solubility.

\section{CONCLUSION}

The best formula made in this research is the addition of a $5 \%$ diethanolamine surfactant. The formula has storage stability of up to $100 \%$ for 5 weeks, with the solubility in water of $80.60 \%$. The lowest surface tension and contact angle values are lower compared to commercial herbicide treatments, which are 30.73 dyne $/ \mathrm{cm}$ and 11.48 o. The size of the droplet produced is quite small compared to the addition of $1 \%$ to $4 \%$ diethanolamine surfactant, which is $7.20 \mu \mathrm{m}$.

\section{ACKNOWLEDGEMENT}

The authors would like to thank the Surfactant and Bioenergy Research Center (SBRC) - LPPM IPB University Baranangsiang for the facilities provided during this research.

\section{REFERENCES}

Aisyah, S. (2011). Produksi Surfaktan Alkil Poliglikosida (APG) dan Aplikasinya pada Sabun Cuci Tangan. Tesis Sekolah Pascasrjana. Institut Pertanian Bogor.

Fardiaz, D., Andarwulan, N., Wijaya, H., Puspitasari, N.L. (1992). Petunjuk Laboratorium Teknik Analisis Sifat Kimia dan Fungsional Komponen Pangan. PAU Pangan dan Gizi Bogor.

Ferdian, M.A., Hambali, E.. \& Rahayuningsih, M. (2016). Studi Perbandingan Produk Insektisida Formulasi EC (Emusifiable Concentrate) dengan Penambahan Surfaktan Dietanolamida menggunakan Vortex, Mixer dan Homogenizer. Jurnal Teknologi Industri Pertanian. 26(1):60-67

Ghosh, V., Mukherjee, A., \& Chandrasekaran, N. (2014). Ultrasonic Emulsification: Reduces Droplet Diameter and Enhances Stability. Journal Pure Applied Ultraconic. 36(1):13-16

Hambali, E., Prijono, D., Suryani, A. (2015). Peningkatan Kinerja Insektisida Nabati dari Ekstrak Mimba (Azadirachtin indica) untuk Pengendalian Hama Ulat Grayak pada Kedelai menggunakan Surfaktan DEA dari Olein sawit. Bogor : SBRC IPB

Hambali, E., Suryani, A., Rivai, M., Sutanto, A.I, Nisya, F.N., Nurkania, A. (2013). Pengembangan Teknologi Proses Produksi Surfaktan Dietanolamida (DEA) dari Metil Ester Olein Sawit dan Aplikasinya untuk Personal Care Products. Bogor : SBRC IPB

Indah, V.S. (2018). Pengembangan Pemanfaatan Gliserol Ester Minyak Sawit sebagai Emulsifier Drilling Fluid berbasis Minyak. Disertasi Sekolah Pascasarjana. Institut Pertanian Bogor.

Indrawijaya, B. (2016). Formulasi Pestisida Nabati Minyak Mimba menggunakan Surfaktan Dietanolamida untuk Pengendalian Hama Ulat Grayak pada Tanaman Kedelai. Tesis Sekolah Pascasarjana. Institut Pertanian Bogor. 
Ivanova NA, Starov VM. 2011. Wetting of low free energy surfaces by aqueous surfactant solutions. Journal Current Opinion in Colloid and Interface Science. 16(4):285-2911

Mcclements, D.J. (2012). Crystals and Crystallization in oil-in-water Emulsions: Implications for Emulsion Based Delivery Systems. Journal Advances in Colloid and Interface Science. 174:1-30. doi: https://doi.org/10.1016/j.cis.2012.03.002

Meizar, D.V. (2016). Penggandaan Skala Produksi Dietanolamida pada Reaktor 25 batch/liter dan Pemanfaatannya pada Insektisida Nabati Minyak Mimba. Tesis Sekolah Pascasarjana. Institut Pertanian Bogor

Mesnage, R,. Defarge, N,. Spiroux de Vendômois, J., \& Séralini, G.E, (2015). Potential Toxic Effects of Glyphosate and its Commercial Formulations below Regulatory Limits. Journal Food Chemical Toxicology. 84:133-53. doi:https://doi.org/10.1016/j. fct. 2015.08.012

Mishra, S. (2015). Aggregation of Surfactants. Tesis. Arcada University of Applied Sciences.

Nisya, F., Hambali, E., Rahmini, Rivai, M., Nobel, C.S., Ari, I.S., Ainun. (2015). Effects of Palm-DEA Non-Ionic Surfactant as an Additive in Buprofezin Insecticide on the Efficacy of it in Controlling Brown Planthopper Rice Pest. Prosiding ICAIA

Pilemand, C. (2002). Surfactants: Their abilities and important physico-chemical properties. DTKommunikation A/S, Copenhagen

Singarimbun BPL. (2012). Pemanfaatan surfaktan berbasis minyak kelapa sawit dalam formulasi herbisida berbahan aktif glifosat. Skripsi. Bogor: Institut Pertanian Bogor.

Suryani A, Hambali E, Sailah I, Rivai M.(2000). Teknologi Emulsi. Teknologi Industri Pertanian. Institut Pertanian Bogor

Suryani, A., Dadang, Setyadjit, Agus, S.T., Mochamad, N.N.K. (2008). Sintesis Alkil Poliglikosida (APG) Berbasis Alkohol Lemak dan Pati Sagu untuk formulasi Herbisida. Jurnal Pasca Panen. 5(1):10-20

Suryani A, Dadang, Nisya FN, Nurkania A (2012). Surfaktan berbasis minyak nabati untuk formuasi herbisida berbahan aktif glifosat. Laporan Penelitian. SBRC IPB. Bogor

Tominack R.L.. (2000). Herbicide Formulations. Journal of Toxicology: Clinical Toxicology 38(2):129-135. doi:http://doi.org/10.1081/ CLT-100100927

Weiss, J., \& Muschiolik, G. (2007). Factors Affecting the Droplet Size of Water-in-Oil Emulsions (W/O) and the Oil Globule Size in Water-in-Oil-in-Water Emulsions (W/O/W). Journal of Dispersion Science and Technology. 28(5):703-716. doi: https://doi. org/10.1080/01932690701341819

Weiss, J., Decker, E.A., McClements, D.J.. Kristbergsson, K,. Helgason, T. \& Awad, T. (2008). Solid Lipid Nanoparticles as Delivery Systems for Bioactive Food Components. Food Biophysics. Journal Food Biophysics. 3(2): 146-154

Zhou L. (2007). Wettability and Dynamic Behavior Of Several Pesticide Surfactant Solutions on Different Targets. Beijing (CN): China Agricultural University 